\title{
Sensory analysis and postharvest of potted gerbera based on fertilization ${ }^{(1)}$
}

\author{
FRANCIELLY TORRES DOS SANTOS(2)*, LUIZ ANTONIO DE MENDONÇA COSTA(2), \\ MÔNICA SAROLLI SILVA DE MENDONÇA COSTA(2)
}

\begin{abstract}
The cultivation of gerberas as cut flowers has been broadly studied. With the purpose of assess the production and visual quality of potted gerberas conducted with different fertilizations, the experiment was performed in a greenhouse located at UNIOESTE - Campus of Cascavel - Parana - Brazil. The experimental design was done in randomized blocks with four repetitions and five treatments. The treatments were defined based on the fertilization source: mineral (NPK) or organic. The organic fertilizations were obtained with the dilution of four organic composts derived from the composting process of agro-industrial wastes in water. The agro-industrial waste, used in different percentages in each treatment, were: grains pre-cleaning residues (corn meal and wheat husk); hatchery waste; flotation sludge; cellulose casing (sausage covering); solid fraction of pig slurry (Piglet Producer Unit) and truck washing; coal and ash remaining from boiler; poultry litter and sugarcane bagasse. The growth parameters were evaluated at the commercialization phase (plant height and diameter, stem height, capitulum number, and capitulum and stem diameter) and sensory analysis through trait and preference assessment tests. The use of liquid organic fertilizers are a feasible alternative to substitute conventional mineral fertilization. Farmers should observe EC values and $\mathrm{K}, \mathrm{Ca}, \mathrm{Mg}$ ratio for better quality assurance according to the results obtained in $\mathrm{T}_{5}$. The $\mathrm{T}_{5}$ (Boiler remaining ash + Hatchery residue) has a larger amount of boiler remaining ash, whereas the chemical elements in mineral form are already readily available to the plants, this fact may have contributed to better visual development of plants grown in this treatment.
\end{abstract}

Keywords: Liquid organic fertilizer, Gerbera jamesonii, mineral nutrition.

\section{RESUMO}

Análise sensorial e pós colheita de gérbera envasada em função da adubação

O cultivo de gérberas como flor de corte tem sido amplamente difundido na literatura. Com o objetivo de avaliar a produção e a qualidade visual de gérberas envazadas conduzidas com adubações diferenciadas, o experimento foi conduzido em estufa, localizada na UNIOESTE - Câmpus de Cascavel - PR. O delineamento experimental foi em blocos casualizados com quatro repetições e cinco tratamentos. Os tratamentos foram definidos em função da fonte da adubação, mineral (NPK) ou orgânica. As adubações orgânicas foram obtidas pela diluição em água de quatro compostos orgânicos provenientes do processo de compostagem de resíduos agroindustriais. Os resíduos agroindustriais, que foram utilizados em diferentes porcentagens em cada tratamento, foram: resíduos da pré-limpeza de grãos (farelo de milho e casquinha de trigo); resíduos de incubatório; lodo de flotador; tripa celulósica (invólucro de salsicha); fração sólida de dejetos de suínos (Unidade Produtora de Leitões) e da lavagem dos caminhões; carvão e cinzas remanescentes da caldeira; cama de matrizeiro e bagaço de cana. Foram avaliados os parâmetros de crescimento no ponto de comercialização (altura e diâmetro da planta, altura da haste, número de capítulos e diâmetro do capítulo e da haste) e a análise sensorial por meio de teste de avaliação de atributos e de preferência. O uso de fertilizantes orgânicos líquidos são uma alternativa viável para substituir a adubação mineral convencional. Os agricultores devem observar os valores da CE e relação de $\mathrm{K}, \mathrm{Ca}, \mathrm{Mg}$ para a garantia de uma melhor qualidade de acordo com os resultados obtidos no $\mathrm{T}_{5}$. $\mathrm{O} \mathrm{T}_{5}$ (cinza de caldeira + invólucro celulósico) apresenta a maior quantidade de cinza de caldeira, ao passo que os elementos químico na forma mineral já estão prontamente disponíveis para as plantas, este fato pode ter contribuído no melhor desenvolvimento visual das plantas cultivadas neste tratamento. Palavras-chave: adubos orgânicos líquidos, Gerbera jamesonii, nutrição mineral.

\section{INTRODUCTION}

Gerbera (Gerbera jamesonii) is an herbaceous plant, belonging to the Asteraceae family (CARDOSO and SILVA, 2013). In the flower market, gerbera stands out due to inflorescence characteristics, such as shape diversity, color range and size, which can vary according to the culture
(DAMASCENO et al., 2010; LONGCHAR and KEDITSU, 2013). Another advantage is related with its short growing cycle (10-12 weeks) (BALL, 2014).

One of gerbera's culture requirements for a rightful handling concerns the appropriate fertilization (LUDWIG et al., 2010; MOTA et al., 2011, SANTOS et al., 2016), both mineral and organic. In regards to organic fertilization

DOI: http://dx.doi.org/10.14295/oh.v23i1.927

(1) Received in 08/08/2016 and accepted in 03/10/2016

(2) Universidade Estadual do Oeste do Paraná (UNIOESTE), Centro de Ciências Exatas e Tecnológicas, Cascavel-PR, Brazil. *Corresponding author: francielly_torres@hotmail.com 
in flower production, alternative materials are currently being used (CABALLERO et al., 2009; DAMASCENO et al., 2010, CONTE-CASTRO et al., 2010; KEDITSU, 2012). Among the sources, the composted agro-industrial wastes, called organic compost, are important alternatives. The organic compost corresponds to the final product resultant from the composting process. It, in turn, provides the transformation of raw organic material into humic substance, stabilized, with completely different properties and characteristics from the original material (KIEHL, 2010).

The transformation of agro-industrial wastes resulted from broiler productive chain into organic compost can result in benefits, such as enabling nutrient recycling and reduction of environmental impact (PRIMO et al., 2011). Yet, organic composts have high concentration of organic matter and nutrients for plants (ABREU et al., 2010).

Nonetheless, due to the high nutritional value of substrates or organic nutritive solutions, caution with the concentration of nutrients, through electric conductivity monitoring (EC), present in these materials is needed (CABALLERO et al., 2009; HERNÁNDEZ et al., 2010). According to Beckmann-Cavalcante et al. (2013), ornamental plants of the family the Asteraceae are classified as moderately sensitive to the nutritive solution's EC. However, the expected fertigation control for proper handling can be performed by $\mathrm{pH}$ quantification and $\mathrm{EC}$ during the culture cycle (MOTA et al., 2011). Thus, the dilution of organic composts in water presents a way of supplying the nutritional needs of gerbera's culture, as well as adjusts the EC.

To assess the result of an efficient fertilization, besides the growth parameters, the sensory analysis can be used. The acceptance of determined product by the consumer is an important step to determine its commercialization. Even though the sensory analysis is the ideal instrument to verify the potential consumer behavior in relation to the product, there are few researches that used this tool to evaluate ornamental plants. In that sense, Ferreira et al. (2001), who worked with sensory analysis of African violets, could be cited as well as Ludwig et al. (2010) that assessed, among possible buyers, the visual quality of gerberas in the commercialization point.

Based on the considerations above, the current study had the purpose of evaluating the usage efficiency of liquid organic fertilizer derived from the dilution of organic composts obtained through the composting of agroindustrial wastes, regarding growth parameters and visual parameters for potted gerbera.

\section{MATERIAL AND METHODS}

The greenhouse presents structure in arch with laterals and canopy made of $150 \mu \mathrm{m}$ transparent plastic, in a total area of $96.0 \mathrm{~m}^{2}$ ( $8 \mathrm{~m}$ of width $\mathrm{x} 12 \mathrm{~m}$ of length) and $2.6 \mathrm{~m}$ of ceiling height. In the interior of the greenhouse, Aluminet ${ }^{\circledR}$ $30 \%$ was installed to guarantee shadow uniformity and diffuser light transmission inside. The average temperature in the interior of the greenhouse was $29.5 \pm 3.68{ }^{\circ} \mathrm{C}$ and the average relative air humidity was $58.5 \pm 12.98 \%$.

The experimental design used was random blocks with five treatments and four repetitions with six pots each and one plant per pot. Totaling 30 sample units per block and a total of 120 pots in the experiment. The treatments were: one mineral fertilization (conventional) and four fertigation regime with different liquid organic fertilizer derived from organic composting of agro-industrial waste (alternative sources).

The mineral fertilization $\left(\mathrm{T}_{1}\right)$ was performed fortnightly with $5 \mathrm{~g}$ of the 4-10-8 formula per pot (every 15 days) (STANCATO, 2015), using $0.2 \mathrm{~g}$ of ammonium sulfate $\left(\left(\mathrm{NH}_{4}\right)_{2} \mathrm{SO}_{4}-21 \%\right.$ of $\left.\mathrm{N}\right) ; 0.4 \mathrm{~g}$ of single superphosphate $\left(\mathrm{P}_{2} \mathrm{O}_{2}\right.$ $-18 \%$ of $\mathrm{P}) ; 0.3 \mathrm{~g}$ of potassium chloride ( $\mathrm{KCl}-61 \%$ of $\mathrm{K})$.

The liquid organic fertilizers were obtained from the dilution of organic composts derived from the composting process of agro-industrial wastes. The initial composition (before composting) for each treatment is shown in Table 1. Each composting pile was prepared with $500 \mathrm{~kg}$ of agroindustrial wastes. The treatments were named according residues with larger amount in production of compounds, $\mathrm{T}_{2}$ : Corn residue + pig manure solid fraction; $\mathrm{T}_{3}$ : Hatchery residue + cellulosic casing; $\mathrm{T}_{4}$ : Pig manure solid fraction + sugar cane bagasse and $\mathrm{T}_{5}$ : Boiler remaining ash + Hatchery residue. 
Table 1. The initial composition of agro-industrial wastes before composting of each treatment and treatment 1 composition

\begin{tabular}{|c|c|c|c|c|c|}
\hline Wastes & $\mathbf{T}_{1}$ & $\mathbf{T}_{2}$ & $\mathbf{T}_{3}$ & $\mathbf{T}_{4}$ & $\mathbf{T}_{5}$ \\
\hline & $-g-$ & \multicolumn{4}{|c|}{ 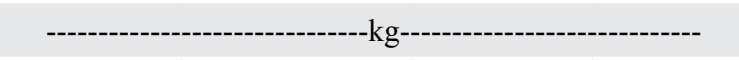 } \\
\hline$\left(\mathrm{NH}_{4}\right)_{2} \mathrm{SO}_{4}-21 \%$ of $\mathrm{N}$ & 0.2 & -- & -- & -- & -- \\
\hline $\mathrm{P}_{2} \mathrm{O}_{2}-18 \%$ of $\mathrm{P}$ & 0.4 & -- & -- & -- & -- \\
\hline $\mathrm{KCl}-61 \%$ of $\mathrm{K}$ & 0.3 & -- & -- & -- & -- \\
\hline Corn residue & -- & 145 & 50 & 0 & 0 \\
\hline Hatchery residue & -- & 80 & 70 & 40 & 35 \\
\hline Flotation sludge & -- & 30 & 50 & 45 & 35 \\
\hline Wheat husks & -- & 50 & 50 & 0 & 0 \\
\hline Cellulosic casing & -- & 20 & 110 & 50 & 75 \\
\hline Pig manure solid fraction & -- & 90 & 45 & 100 & 75 \\
\hline Boiler remaining coal & -- & 25 & 30 & 70 & 30 \\
\hline Boiler remaining ash & -- & 30 & 30 & 80 & 150 \\
\hline Truck wash residue solid fraction & -- & 30 & 45 & 15 & 15 \\
\hline Poultry litter & -- & 0 & 50 & 0 & 10 \\
\hline Sugar cane bagasse & -- & 0 & 0 & 100 & 75 \\
\hline
\end{tabular}

T1: Mineral fertilizer source; T2: Corn residue + Pig manure solid fraction; T3: Hatchery residue + Cellulosic casing; T4: Pig manure solid fraction + Sugar cane bagasse and T5: Boiler remaining ash + Hatchery residue.

At the end of the composting process, organic composts with EC values higher than those recommended to gerbera culture were generated: $5.63 ; 8.29 ; 3.63$ and $5.46 \mathrm{dS}$ $\mathrm{m}^{-1}$, for treatments $2,3,4$ and 5 , respectively. Thereby, it wouldn't be possible to use the organic composts as a substrate for gerbera production. Therefore, the dilution of organic composts was preceded, in order to utilize only the liquid fraction as fertigation for the culture.

To reach the ideal dilution of organic composts, tests were performed. With the purpose of guarantee a proper EC for gerbera fertigation, $27 \mathrm{~kg}$ of each organic compost were used, and placed in $100 \mathrm{~L}$ barrels, a quantity of organic compost that corresponded to $1 / 3$ of the total blend. The volume was completed with artesian well water and the solution was manually stirred for 30 minutes every day for 60 days. After this period, the solution was filtered and only the liquid phase, called liquid organic fertilizers (LOF), was used. The dilution of compounds was based on potassium element, according to the indication Ludwig et al. (2008). The LOF's were chemically characterized. The total nitrogen was quantified by digestion in a Kjedahl distiller, according to methodology suggested by Malavolta et al. (1997). The macronutrients and micronutrients were determined according EMBRAPA's methodology (2009).

The experimental unit consisted of a number 14 plastic pot $(10.5 \mathrm{~cm}$ of height, $12.5 \mathrm{~cm}$ of superior diameter and $10.0 \mathrm{~cm}$ of inferior diameter), filled with $900 \mathrm{~mL}$ of commercial substrate (Tropstrato HT, Mogi Mirim, Brazil). The commercial substrate used was produced with pine bark, peat, vermiculite, single superphosphate and potassium nitrate (composition indicated by the manufacturer). The chemical characteristics presented are E.C $0.5 \mathrm{dS} \mathrm{m}{ }^{-1}$; $\mathrm{pH} 5.8$; in $\mathrm{g}$ $\mathrm{kg}^{-1}$ : N 0.06; P 0.001; K 0.06; Ca 0.55; $\mathrm{Mg} 0.28$ in mg kg-1: $\mathrm{Na}$ 575.47; $\mathrm{Cu}$ 0.27; Fe 275.27; Mn 3.587 and Zn 4.08. The physical characteristics given by the manufacturer were: $60 \%$ humidity, $130 \%$ water retention capacity, 500 humid density.

Phytosanitary management was organically performed in all plants. Bordeaux mixture was applied weekly to prevent fungus. Gerbera 'Florist Red Black' seedlings with four definite leaves were used. The seedlings were acquired in platter, from Ball ${ }^{\circledR}$ Horticultural do Brasil Ltda (Holambra, Brazil), transplanted to the pots and remained in acclimatization for 15 days, irrigated only with water. After this period, the mineral fertilization started, as well as the organic fertigation.

The mineral and organic fertilization treatments were performed based on daily weighting of pots, taking into consideration, the evapotranspiration of the day. The pots were kept at $70 \%$ of water retention capacity in the vegetative period and at $80 \%$ of water retention capacity in the reproductive period. The maximum amount of available water in the substrate was defined based on the substrate's water retention capacity, inspected by weighting of 10 pots per block. The irrigation average was $120 \pm 30.48$ $\mathrm{mL}$ pot $^{-1}$ day $^{-1}$. The irrigation and fertigation were done manually with the use of graduated vessels. On Table 2, the total of available nutrients in the whole culture cycle in all treatments is presented. 
Table 2. Total amount of nutrients provided for potted gerbera 'Florist Red Black' during the 56 days of experiment in treatments 1 to 5 .

\begin{tabular}{|c|c|c|c|c|c|}
\hline \multirow{2}{*}{ Treatments } & \multicolumn{5}{|c|}{ Macronutrients } \\
\hline & Nitrogen & Phosphorus & Potassium & Magnesium & Calcium \\
\hline & $\mathrm{g}$ & $\mathrm{mg}$ & g & $\mathrm{mg}$ & g \\
\hline $\mathrm{T}_{1}^{*}$ & 0.16 & 126.00 & 0.61 & * & $*$ \\
\hline $\mathrm{T}_{2}^{* *}$ & 111.17 & 0.57 & 1.54 & 379.28 & 2.39 \\
\hline $\mathrm{T}_{3}^{* *}$ & 77.91 & 0.31 & 1.41 & 244.59 & 1.96 \\
\hline $\mathrm{T}_{4}^{* *}$ & 26.80 & 0.36 & 0.89 & 190.12 & 1.08 \\
\hline $\mathrm{T}_{5}^{* *}$ & 72.80 & 0.29 & 1.95 & 394.49 & 1.18 \\
\hline \multirow{3}{*}{ Treatments } & \multicolumn{5}{|c|}{ Micronutrients } \\
\hline & Sodium & Zinc & Manganese & Iron & Copper \\
\hline & \multicolumn{5}{|c|}{ 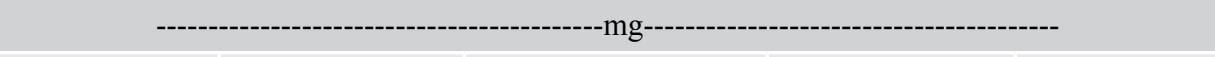 } \\
\hline $\mathrm{T}_{1}^{*}$ & $*$ & $*$ & $*$ & * & $*$ \\
\hline $\mathrm{T}_{2}^{* *}$ & 716.12 & 8.56 & 4.69 & 242.48 & 2.27 \\
\hline $\mathrm{T}_{3}^{* *}$ & 551.74 & 7.07 & 10.45 & 183.70 & 0.12 \\
\hline $\mathrm{T}_{4}^{* *}$ & 910.42 & 9.04 & 0.32 & 80.44 & 0.26 \\
\hline $\mathrm{T}_{5}^{* *}$ & 501.86 & 2.42 & 2.02 & 92.81 & 0.82 \\
\hline
\end{tabular}

$* \mathrm{~T}_{1}$ : Mineral fertilizer source $* * \mathrm{~T}_{2-5}:$ Organic compost fertilizer source.

The pots were arranged on tables $(0.80 \mathrm{~m}$ of width $\mathrm{x}$ $2.20 \mathrm{~m}$ of length). After the leaves superposition, pots were spaced at $0.20 \times 0.20 \mathrm{~m}$. The experimental evaluation started after the acclimatization and the results were expressed in days after the acclimatization (DAA).

The plants were assessed in the commercialization phase, at 56 DAA. The plant height $(\mathrm{PH})$ was determined using a millimeter-graduated ruler, from its insertion in the pot up to the highest leaf. The plant diameter (PD) from two opposite extremities of the plant, perpendicular to each other. The floral stem height (FSH) was measured from the of start floral stem height until the beginning of the capitulum. The floral stems diameter (FSD) was measured at five centimeters below the floral capitulum with a digital pachymeter (Eletronic Digital Vernier Caliper, MT00855, Uyustools, Hangzhou, China) which was also used to measure the capitulum diameter (DC), adopting two extreme points perpendicular to each other, according to the methodology suggested by Ludwig et al. (2010).

For the sensory analysis, it was evaluated color, size and general appearance of the leaves and the flowers in the commercialization phase at 56 DAA. The methodology used in the sensory analysis was suggested by Ureña et al. (1999).

The sensory analysis was performed by discriminative methods (trait evaluation tests) measured with a hedonic scale, with nine numeric points with limits from: one (extreme dislike) to nine (extreme like). To test the preference, the potential consumers should answer the preference test using the question: "In your opinion as a consumer, which one of these plants would you buy?"
(UREÑA et al. 1999). The sensory analysis was done among 35 non-trained judges chosen at random, constituted by students, employees and teachers at UNIOESTE - Cascavel Campus - PR/Brazil.

The experimental design used was entirely randomized, with 35 repetitions, representing the judges. The research was approved by UNIOESTE/ Cascavel - PR ethical committee in researches with human beings (CEP).

Initially, an exploratory data analysis was executed and assumptions on variance analysis were checked. Afterwards, the data was subjected to variance analysis to verify if there was any significant treatment effect. The Tukey test was applied at $5 \%$ of probability for average comparison.

\section{RESULTS AND DISCUSSION}

Gerberas cultivated with liquid organic fertilizer (LOF) present similar development to those cultivated with mineral fertilization when parameters of growth and development of the aerial part in the commercialization phase were evaluated.

This performance is directly related to nutrients supply. Amongst macronutrients, potassium is the most absorbed element by gerbera, deserving special attention, especially in the blooming stage (GUERRERO et al., 2012). Medeiros et al. (2010) observed that the increase of nitrogen, despite providing an increase in the number of buds and reducing the time of their emission, caused a negative effect in terms of quality of the flowers produced; the increase of potassium, though, was benefic. In a work done with 
hydroponic gerberas assessing the different relationships between K: $(\mathrm{K}+\mathrm{Ca}+\mathrm{Mg})$, Savvas and Gizas (2002) concluded that the balance in this relation must be close to 0.56 meq to meet the plant's absorption needs. In this work, the treatment that received the highest amount of potassium was $\mathrm{T}_{5}$ (Boiler remaining ash + Hatchery residue). This same treatment was also the one that presented the closest value to the ideal $\mathrm{K}$ relation: $(\mathrm{K}+\mathrm{Ca}+\mathrm{Mg}), 0.55 \mathrm{meq}$ and also it was best assessed by the judges.

The growth parameters are presented in Table 3 (plant height and diameter, stem height, and capitulum and stem diameter).

Table 3. Plant height (PH), floral stem height (SH), plant diameter (PD), capitulum diameter (CD) and floral stem diameter (FSD), at 56 days after acclimatization in plants fertilized with mineral source only $\left(\mathrm{T}_{1}\right)$ and organic compost fertigation $\left(\mathrm{T}_{2-5}\right)$.

\begin{tabular}{|c|c|c|c|c|c|}
\hline \multirow{2}{*}{ Treatments } & PH & SH & PD & CD & FSD \\
\cline { 2 - 6 } & $\mathrm{cm}$ & $\mathrm{cm}$ & $\mathrm{cm}$ & $\mathrm{mm}$ & $\mathrm{mm}$ \\
\hline $\mathrm{T}_{1}$ & $22.92 \pm 0.51 \mathrm{c}$ & $17.55 \pm 1.00 \mathrm{~b}$ & $24.05 \pm 1.67 \mathrm{a}$ & $86.07 \pm 0.47$ & $4.44 \pm 0.45$ \\
\hline $\mathrm{T}_{2}$ & $24.67 \pm 0.51 \mathrm{~b}$ & $22.20 \pm 0.52 \mathrm{a}$ & $20.22 \pm 0.74 \mathrm{~b}$ & $82.90 \pm 0.65$ & $4.46 \pm 0.25$ \\
\hline $\mathrm{T}_{3}$ & $20.35 \pm 0.31 \mathrm{~d}$ & $20.32 \pm 0.76 \mathrm{ab}$ & $21.60 \pm 1.29 \mathrm{ab}$ & $88.42 \pm 0.82$ & $4.54 \pm 0.12$ \\
\hline $\mathrm{T}_{4}$ & $19.62 \pm 0.40 \mathrm{~d}$ & $18.02 \pm 0.53 \mathrm{~b}$ & $23.92 \pm 0.91 \mathrm{a}$ & $90.42 \pm 0.66$ & $4.52 \pm 0.23$ \\
\hline $\mathrm{T}_{5}$ & $26.97 \pm 0.40 \mathrm{a}$ & $23.30 \pm 2.51 \mathrm{a}$ & $20.65 \pm 2.59 \mathrm{~b}$ & $79.70 \pm 0.18$ & $4.43 \pm 0.19$ \\
\hline $\mathrm{CV} \%$ & 2.39 & 6.89 & 6.56 & 7.24 & 6.43 \\
\hline P-values & 0.001 & 0.028 & 0.031 & 0.553 & 0.923 \\
\hline
\end{tabular}

Averages followed by the same letter in the column don't differ from each other according to the Tukey test at a 5\% probability level.

The Brazilian Institute of Floriculture (IBRAFLOR, 2013) elaborated the quality standard for potted gerbera, with essential factors for the plant's quality. Among these factors are the plant's height, number of flowers and the flower opening point. Regarding the plant's height, IBRAFLOR recommends that the ideal size should be between 14 and $30 \mathrm{~cm}$ for commercialization of gerberas cultivated in a number 14 vase. In the current study, the gerberas cultivated in all treatments are within this recommendation. However, $\mathrm{T}_{5}$ (Boiler remaining ash + Hatchery residue) presented $26.97 \pm 0.74 \mathrm{~cm}$, a value statistically superior to the others. Ludwig et al. (2013) found the value of $19.9 \mathrm{~cm}$ of height for gerberas produced with coconut fiber substrate. Higher results for the same cultivar were recorded by Ludwig et al. (2010), with 29.7 $\mathrm{cm}$ of plant height.

The stem diameter didn't show statistical difference between treatments in this study. The stem diameter is important, since it's related to a higher shelf life in relation to the capitulum support, avoiding a possible fall and quality loss, especially during transport and handling (LUDWIG et al., 2011).

Regarding the number of capitula, the treatments didn't demonstrate variance homogeneity. Therefore, the average comparison was not possible to be performed. According to the descriptive analysis, the general average in all treatments for the number of capitula was 2.5. The number of capitula in potted plants enhances the final product value and can be decisive for commercialization. It's possible to raise the number of capitula through the practice of floral thinning and cycle increase, however, it means a rise in production cost (LUDWIG et al., 2010). Nonetheless, the gerbera market requirement is for the plant to have at least two open inflorescences and, thus, all treatments attended this parameter.

Another classification suggested by IBRAFLOR (2014) refers to the quality of the plant cultivated in a pot number 14 , according to the amount of flowers per pot, which goes from class I (one flower) to class IV (four flowers). Considering the results of this experiment, it was observed an average of two flowers per pot, therefore, class II.

The plant diameter was influenced by the treatments in the current study; lower diameters were obtained in $\mathrm{T}_{2}$ (Corn residue + Pig manure solid fraction) with $20.22 \pm$ $0.74 \mathrm{~cm}$ and $\mathrm{T}_{5}$ (Boiler remaining ash + Hatchery residue) with $20.65 \pm 2.59 \mathrm{~cm}$, not differing from $\mathrm{T}_{3}$ (Hatchery residue + Cellulosic casing) with $21.60 \pm 1.29 \mathrm{~cm}$. Thus, the plant diameter values are lower than the ideal indicated by Ludwig et al. (2011) between 29.0 and $31.0 \mathrm{~cm}$. The authors attribute the diameter of the plant foliar surface and foliar area as important factors for commercialization of potted gerberas. Ludwig et al. (2010) obtained values of plant diameter between 28.36 and $30.23 \mathrm{~cm}$, for gerbera 'Red' and 'Cherry', respectively.

In capitulum diameter, the evaluated treatments didn't present significant statistical difference. The values obtained in this study for capitulum diameter were between $7.9 \pm$ $0.18 \mathrm{~cm}$ in $\mathrm{T}_{5}$ (Boiler remaining ash + Hatchery residue) and 
$9.0 \pm 0.65 \mathrm{~cm}$ in $\mathrm{T}_{4}$ (Pig manure solid fraction + Sugar cane bagasse). However, Ludwig et al. (2010) researched the 'Cherry', 'Golden Yellow', 'Salmon Rose' and 'Orange', using two nutritive solutions. The authors verified that the inflorescence diameter (capitulum) was higher for 'Salmon Rose' $(10.31 \mathrm{~cm})$ and lower for 'Yellow' $(8.77 \mathrm{~cm})$, with the capitulum diameter being a characteristic influenced, especially, by genetic potential.

On Figure 1 it is presented the marks assigned in the sensory analysis, for leaves and flowers quality, regarding color, size and general appearance of gerberas cultivated in mineral fertilization and organic fertigation.
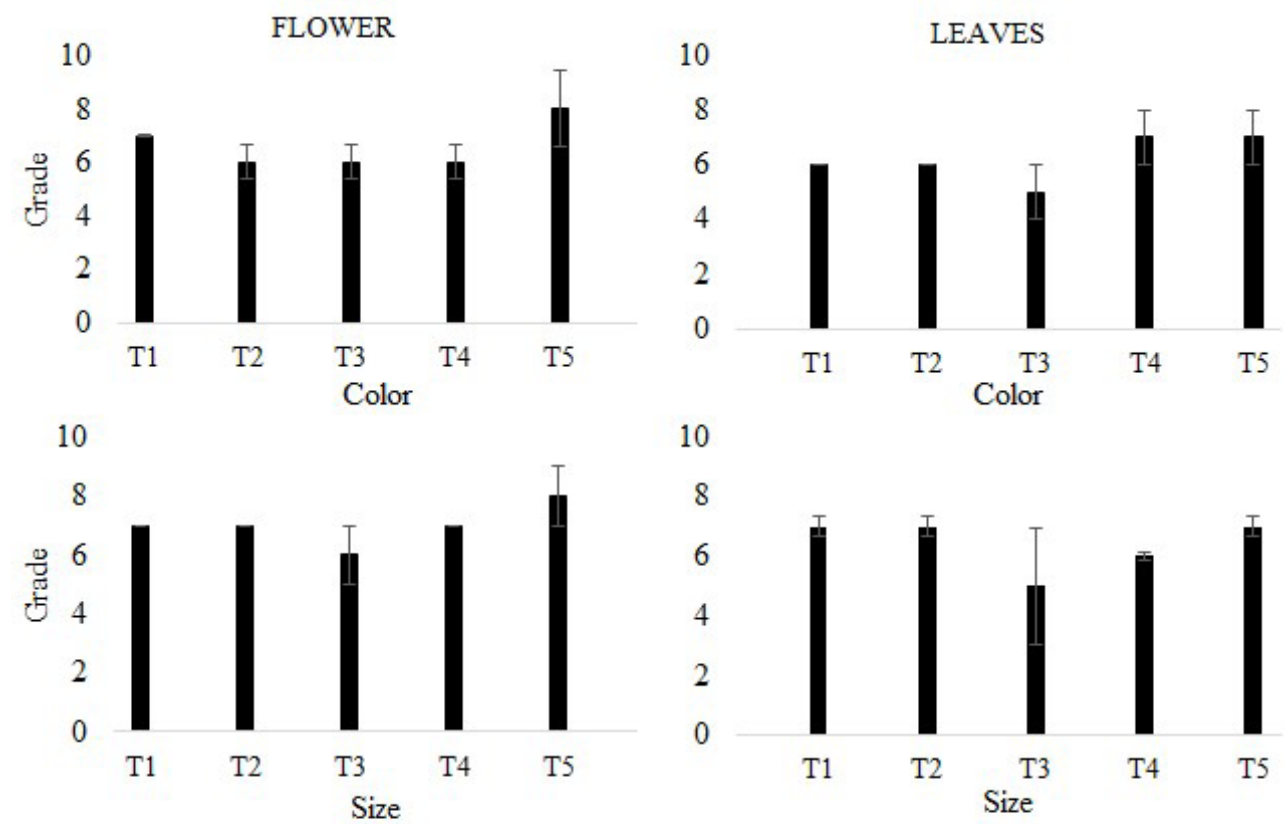

10
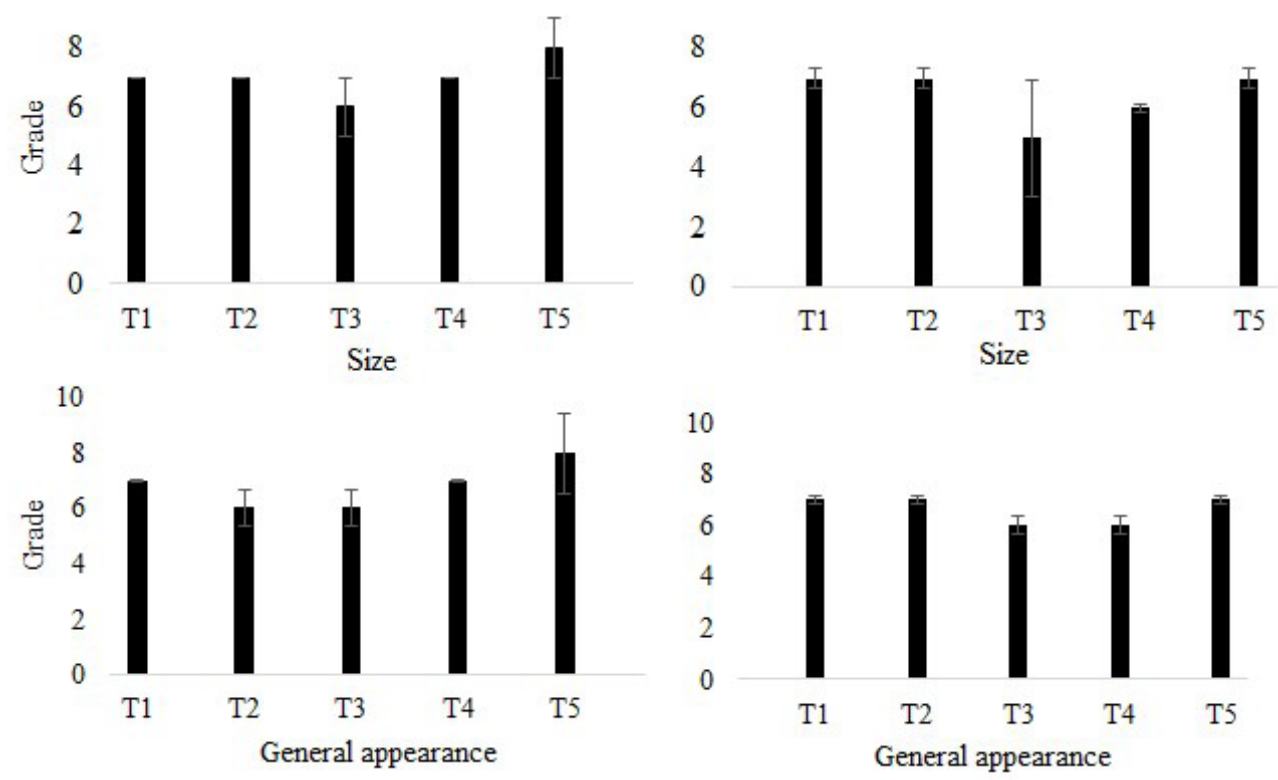

Figure 1. Grades assigned for potted gerbera's flowers and leaves 'Florist Red Black' $T_{1}$ : Mineral fertilization fertilizer source. $\mathrm{T}_{2-5}$ : Organic compost fertilizer source. Data represents means \pm standard deviation.

It should be noted that the color trait of gerbera leaves assessment showed a significant difference among treatments. The treatments $\mathrm{T}_{1}$ (mineral fertilization), $\mathrm{T}_{2}$ (Corn residue + Pig manure solid fraction) and $\mathrm{T}_{5}$ (Boiler remaining ash + Hatchery residue), according to the judges, have the ideal leaf color. For the leaves size trait, $\mathrm{T}_{3}$ (Hatchery residue + Cellulosic casing) and $\mathrm{T}_{4}$ (Pig manure solid fraction + Sugar cane bagasse) demonstrated the lowest average marks. This fact could be related to the plant height. Despite all treatments being within the values indicated by IBRAFLOR, $\mathrm{T}_{3}$ (Hatchery residue + Cellulosic casing) and $\mathrm{T}_{4}$ (Pig manure solid fraction + Sugar cane bagasse) showed lower plant height when compared with the other treatments, i.e. $20.35 \pm 0.31$ and $19.62 \pm 0.40 \mathrm{~cm}$, respectively. According to Ludwig et al. (2010) this indicates that the leaves of those plants were less developed, and there's a preference by the consumer for vases with good leaves structure. Thus, larger leaves present higher aesthetic quality.

The treatments $\mathrm{T}_{1}$ (mineral fertilization), $\mathrm{T}_{2}$ (Corn residue + Pig manure solid fraction) and $\mathrm{T}_{5}$ (Boiler remaining ash + Hatchery residue) achieved the highest marks for the leaves general appearance, thus, it can be noted that according to the judges the visual quality of the leaves can be related to the plant diameter, since the higher diameter obtained was $24.05 \pm 1.67 \mathrm{~cm}$ on $\mathrm{T}_{1}$ (mineral fertilization), but the plant diameter didn't differ between $\mathrm{T}_{3}$ (Hatchery residue + Cellulosic casing) and $\mathrm{T}_{4}$ (Pig manure solid fraction + Sugar cane bagasse).

In the flowers evaluation, there was a significant difference for the color, size and general appearance traits. For the color characteristics, the $\mathrm{T}_{5}$ (Boiler remaining ash + Hatchery residue) reached the highest marks, i.e. $8 \pm 1.26$, however, there was no statistical difference in 
comparison to $\mathrm{T}_{4}$ (Pig manure solid fraction + Sugar cane bagasse), i.e. $7 \pm 1.19$. The same occurred with the size characteristics of the plants analyzed.

For the flowers general appearance, $\mathrm{T}_{5}$ (Boiler remaining ash + Hatchery residue) had the highest average; such fact could be related to the plant height , since it was evidenced in this study that visually, the plants that show plant height have the buyer's preference. Ferreira et al. (2001), despite working with African violets, also observed by sensory analysis that plants with higher development and vigor were more attractive to consumers.

In addition to evaluation tests on flowers and leaves characteristics, it was performed a preference test and for this purpose the following question was applied: "In your opinion as a consumer, which of these samples would you buy? " Among the judges, with a preference of $62.85 \pm$ $8.71 \%$, the plants subjected to $\mathrm{T}_{5}$ (Boiler remaining ash + Hatchery residue) were the favorite due to their better appearance and higher scores compared to the others. The $\mathrm{T}_{5}$ (Boiler remaining ash + hatchery residue) was composed by a larger amount of boiler remaining ash, where the chemical elements in mineral form are already readily available to the plants, this fact potentially contributed to the improved development of plants grown in this treatment.

The aesthetic quality parameters vary among different kinds of ornamental plant. Specifically for potted flower, it must be considered not only the inflorescence, but also the foliage, and even more important, the set formed by inflorescence and leaves. $T_{3}$ (Hatchery residue + Cellulosic casing) didn't receive any intention of purchase, since it had some of the lowest marks regarding flowers and leaves characteristics assessed by the judges.

\section{CONCLUSIONS}

The use of liquid organic fertilizers is a feasible alternative to substitute conventional mineral fertilization. Farmers should observe EC values and $\mathrm{K}, \mathrm{Ca}, \mathrm{Mg}$ ratio for better quality assurance according to the results obtained in $\mathrm{T}_{5}$ (Boiler remaining ash + Hatchery residue).

\section{REFERENCES}

ABREU,M.F.;ABREU, C.A.; SARZI, I.; PADUAJUNIOR, A.L. Extratores aquosos para a caracterização química de substratos para plantas. Horticultura Brasileira, v.25, n.2, p.184-187, 2007.

BALL. Informações culturais sobre a gérbera cultivada em vaso. Available at: $<$ http://www.ball.com. br/web/arquivos/Ball\%20Informacoes\%20Culturais\%20 Gerbera\%2020060520.pdf.> Accessed: 20 January 2014.
BECKMANN-CAVALCANTE, M.Z.; PIVETTA, K.F.L.; CAVALCANTE, Í.H.L.; CAVALCANTE, L.F.; SILVA JÚNIOR, J.V.S. Nutritional status of the potted chrysanthemum relative to electrical condutivity and salt leaching. Revista Ciência Agronômica, v.44, n.1, p.782789, 2013.

CABALERRO, R.; PAJUELO, P.; ORDOVA, J.; CARMONA, E.; DELGADO, A. Evaluation and correction of nutrient availability to Gerbera jamesonii $\mathrm{H}$. Bolus in various compost-based growing media. Scientia Horticulturae, v.122, p.244-250, 2009.

CARDOSO, J.C.; SILVA, J.A.T. Gerbera micropropagation. Biotechnology Advances, v.31, n.8, p.1344-1357, 2013.

CASTRO, A.M.C.; SILVA, S.C.; PAULETTI, D.R.; SPACKI, A.P.; VACARIN, R.N.D.; SILVA, L.P.E.; DARTORA, J. Resíduos orgânicos no cultivo de crisântemo e em alguns atributos físicos do solo. Agrarian, v.1, n.1, p.21-35, 2008.

DAMASCENO, L.M.O.; ANDRADE JÚNIOR, A.S.; GHEYI, H.R.; RIBEIRO, V.Q.; DIAS, N.S. Cultivation of gerbera irrigated with treated domestic effluents. Revista Brasileira de Engenharia Agrícola e Ambiental, v.14, n.6, p.582-588, 2010.

EMBRAPA. Manual de análises químicas de solos, plantas e fertilizantes. Brasília: EMBRAPA, 2009. 627p.

FERREIRA, I.T.; SOUZA, J.A.; ROCHA, M.T.R.; VIEGAS, J.; SILVA, J.B. Violetas africanas, micropropagadas: cultivo em diferentes substratos. Revista Brasileira de Horticultura Ornamental, v.7, n.1, p.117-127, 2001.

GUERRERO, A.C.; FERNANDES, D.M.; LUDWIG, F. Acúmulo de nutrientes em gérbera de vaso em função de fontes e doses de potássio. Horticultura Brasileira, v.30, n.2, p.201-208, 2012.

HERNÁNDEZ, A.; CASTILLO, H.; OJEDA, D.; ARRAS, A.; LÓPEZ, J.; SÁNCHEZ, E.; Effect of vermicompost and compost on lettuce production. Chilean Journal of Agricultural Research, v.70, n. 4, p.583-589, 2010.

IBRAFLOR - Instituto brasileiro de floricultura. 2013. Critério de classificação de gérbera em vaso pote 14 . Available at: http://www.ibraflor.com/p_qualidade.php. Accessed: 20 January 2014.

KEDITSU, R. Response of Gerbera to inorganic fertilization versus organic manuring. Annals of Plant and Soil Research, v.14, n.1, p.163-166, 2012. 
KIEHL, J.E. Novo Fertilizantes Orgânicos. Piracicaba: Editora Degaspari, 2010. 248p.

LONGCHAR, A.; KEDITSU, R. Flower yield and vase life of Gerbera in response to planting time and organic manures on Alfisol. Scientific Journal of Agricultural, v.2, n.1, p.124-128, 2013.

LUDWIG, F.; FERNANDES, D.M.; GUERRERO, A.C.; VILLAS BÔAS, R.L. Nutrient uptake in potted gérbera cultivars. Revista Horticultura Brasileira, v.31, n.1, p.622-627, 2013.

LUDWIG, F.; FERNANDES, D.M.; MOTA, P.R.D.; BOAS, R.L.V. Macronutrientes em cultivares de gérbera sob dois níveis de fertirrigação. Revista Horticultura Brasileira, v.26, n.1, p.68-73, 2008.

LUDWIG, F.; FERNANDES，D.M.; MOTA， P.R.D.; VILLAS BÔAS, R.L. Crescimento e produção de gérberas fertirrigadas com soluções nutritivas. Revista Horticultura Brasileira, v.28, n.1, p. 424-429, 2010.

LUDWIG, F.; GUERRERO, A.C.; FERNANDES, D.M.; VILLAS BÔAS, R.L. Qualidade de cultivares de gérbera de vaso em função de características físicas e químicas dos substratos. Revista Brasileira de Horticultura Ornamental, v.17, n.1, p.141-148, 2011.

MALAVOLTA, E.; VITTI, G.C.; OLIVEIRA, S.A. Avaliação do estado nutricional das plantas. Piracicaba: Potafos, 1997.319p.

MEDEIROS, S.S.; SOARES, F.A.L.; GHEYI, H.R.; FERNANDES, P.D. Uso de água residuária de origem urbana no cultivo de gérberas: efeitos nos componentes de produção. Engenharia Agrícola, v.27, n.2, p.569-578, 2007.
MOTA, P.R.D.; VILLAS BÔAS, R.L.; LUDWIG, F.; FERNANDES, D.M.; FOLEGATTI, M.V. Avaliação do $\mathrm{pH}$ e condutividade elétrica em substrato sob diferentes níveis de fertirrigação e métodos de extração da solução. Revista Brasileira de Horticultura Ornamental, v.17, n.2, p.121-126, 2011.

PRIMO, D.C.; MENEZES, T.O.; SILVA, T.O. Substâncias húmicas da matéria orgânica do solo: uma revisão de técnicas analíticas e estudos no nordeste brasileiro. Scientia Plena, v.7, n.1, p. 1-13, 2011.

SANTOS, F.T., LUDWIG, F., COSTA, L.A.M., COSTA, M.S.S. de M., REMOR, M.B., SILVA, P.E.R. Growth analysis of potted gerbera conducted with mineral fertilization and organic fertigation. Ciencia e Investigación Agraria, v.43, n.1, p.111-120, 2016. DOI: $<$ http://dx.doi.org/10.4067/rcia.v43i1.1555>

SAVVAS, D.; GIZAS, D.G. Response of hydroponically grown gerbera to nutrient solution recycling and different nutrient cations ratios. Scientia Horticulturae, v.96, n.1, p.267-280, 2002.

STANCATO, G.C. Gérbera. Available at: $<$ http://revistagloborural.globo.com/Revista/ Common/0,ERT168359-18293,00.html> Accessed: 05 February 2014.

UREÑA, M.P.; D’ÁRRIGO, M.H.; GIRÓN, O.M. Evaluación sensorial de los alimentos. Peru: Universidade Nacional Agrária La Molina, 1999. 97p. 